\title{
Assessing post-harvest labor shortages, wages, and welfare
}

\author{
Andrew J. Cassey ${ }^{1 *}$ (D, Kwanyoung Lee ${ }^{1}$, Jeremy Sage ${ }^{2}$ and Peter R. Tozer ${ }^{3}$
}

\author{
* Correspondence: cassey@wsu.edu \\ ${ }^{1}$ School of Economic Sciences, \\ Washington State University, \\ Pullman, WA, USA \\ Full list of author information is \\ available at the end of the article
}

\begin{abstract}
For horticultural commodities, labor is necessary for post-harvest activities such as management, marketing, packing, and distribution. We create a model with pre- and post-harvest tasks and transportation network to study how a shortage in the pre-harvest labor market affects the post-harvest labor market and downstream commodity markets. Parameterized to U.S. pome and prunus industries, we find output prices are $16 \%$ greater, the prunus industry does less well adjusting, and producers benefit despite output reductions. Producers' benefit comes almost exclusively from higher prices, but decreases when the resulting post-harvest labor shortage increases spoilage along the transportation network.
\end{abstract}

Keywords: Post-harvest, Labor shortage, Transportation, Pome, Prunus, Welfare JEL classification: J43, Q13

\section{Background}

Labor is an important input into the production and distribution of horticultural commodities and products. In papers such as Richards and Patterson (1998), labor shortages are usually thought of as a pre-harvest problem, and the economic impacts are estimated from models related to harvesting and production. Although labor is necessary for growing and harvesting horticultural commodities, it is also an important input into managing, marketing, processing, packing, transporting, and distributing fresh commodities to market post-harvest. The purpose of this paper is to study the effects of a pre-harvest labor shortage on employment and wages in the post-harvest labor market, the price and quantity sold in output markets, and economic welfare. That the economic consequences of pre-harvest labor shortages on post-harvest labor activities and downstream commodity markets are unknown is an important problem because of the frequency pre-harvest labor shortages are expected to occur in the future (Taylor et al. 2012).

We define a labor shortage as the difference between the number of workers willing, able, and available to work and the number of workers desired by producers given the going market wage. Pre-harvest activities are those related to construction, soil preparation, grounds maintenance, farming, production, and harvest. Post-harvest is the time when the bulk of the crop is separated from its parent plant to purchase by a consumer. It is the stage of the process covering the cooling, cleaning, sorting, packing, 
and transporting of products to consumers. We also include in post-harvest activities those tasks related to management, operations, bookkeeping, marketing, purchasing, and sales. Our partition of tasks into pre-harvest and post-harvest is based on the description and timing of each occupation related to crop support. The partition of tasks is not based on the education or experience of the workers. For example, we classify production workers and the managers of production workers as pre-harvest tasks.

To understand the effects of a pre-harvest labor shortage on the post-harvest labor and output commodity markets, we consider an economy that comprises two input markets and two output markets. Both output markets draw employment from each input labor market. The input markets are the pre-harvest and post-harvest labor markets. The output markets we consider are the U.S. pome (apple) and prunus (peach) commodity markets. We choose these industries because of their large total value of fresh production-almost $\$ 3.2$ billion in 2013-and their geographic spread across the contiguous states -32 for pome and 20 for prunus (USDA-NASS). Therefore, our findings will apply to multiple states as well as being illustrative of the problem to the greater agricultural sector. We also focus on these industries because of their similarities in production and delivery techniques. However, the two industries differ in size, spoilage rates, and in demand characteristics thus allowing us to observe differential impacts from a pre-harvest labor shortage that would be hidden if we considered the fruit sector in aggregate. ${ }^{1}$

We place the two input and two output markets into an equilibrium displacement model. Using estimates from Brady et al. (2016), we shock the model with a 5.4\% increase in commodity demand from population growth and also a $7.0 \%$ decrease in pre-harvest labor supply. Under a competitive scenario, we estimate wages of pre- and post-harvest labor would need to increase by $6.7 \%$ and $3.5 \%$ for the markets to clear. Under a scenario where we create a labor shortage by exogenously fixing wages at their pre-shock level, we estimate price increases by about $16 \%$ for both pome and prunus compared to the post-shock competitive equilibrium and output decreases by $8.1 \%$ for pome and $18.8 \%$ for prunus. The deadweight loss associated with the estimated labor shortages are $\$ 87.5$ million for the pome and prunus output markets combined and $\$ 44.1$ million for the labor markets combined, measured in 2013 dollars. Yet despite the inefficiency in the economy from the labor shortage, producers' welfare increases relative to the competitive outcome because the labor-shortage-induced decrease in output is more than made up for by the increased prices obtained by sellers.

We then consider how the post-harvest labor shortage will increase commodity-specific spoilage along the transportation network by reducing the amount of production that is able to be sold. This is an important part of the production and delivery process that is missing from most studies. We find the prunus industry is affected by the labor shortage before the pome industry. This differential effect is due to the size of the pome industry in relation to the prunus industry, that prunus spoils 33\% more quickly than pome and that the pome industry faces a less price elastic demand. Thus, the pome industry is able to pass higher prices from a labor shortage onto the consumer more readily than the price-sensitive prunus industry.

The next section documents that agricultural labor shortages do occur, which means that wages do not fully adjust to shocks competitively. That motivates the design of our model, described in section "A Two Good Equilibrium Displacement Model with 
Labor," and our comparative static exercise. We describe the parameters values and data we use in sections "Parameterization and Shocks" and "Data and the Benchmark Economy." The results, in which we compare the post-shock competitive equilibrium to an outcome where wages are fixed to create a labor shortage, are in section "Results and discussion."

\section{Labor shortages and fixed wages}

Labor shortages occur in agriculture, suggesting that the labor market is not perfectly competitive. Hertz and Zahniser (2013) and Taylor et al. (2012) are among the papers providing evidence that pre-harvest labor shortages commonly occur. Agricultural labor shortages have become such an issue that awareness of them has spread from the industry to the general public. Examples in the media include Brat (2015) and Fyksen (2015). That labor shortages occur implies wage in the pre-harvest labor market does not fully or competitively adjust to shocks. Fisher and Knutson (2013) argue the reason wage is sticky is the fixed cost from labor moving between geographic regions and also between commodity-specific tasks. They argue that agricultural labor is not particularly mobile, as often believed. Thus, the combination of geography and commodity specificity creates localized labor markets, where labor shortages could be masked by data at the national level. Another possibility is that global commodity prices prevent wages from increasing. Wells (2012) reports labor shortages may shift U.S. agricultural production to Mexico or China rather than increasing wages to the competitive rate.

There is also evidence that the post-harvest labor market does not have wages that adjust competitively either (Min and Lambert 2002). Despite advances in the environmental and biological control of post-harvest loss, socioeconomic constraints exist throughout the post-harvest supply chain creating wage rigidity (Kader 2005). Kantor et al. (1997) estimate that post-harvest losses in the USA can be as large as $23 \%$ for fruit. Producers, regardless of size, may find the marketing, distribution, and delivery process cumbersome as they acquire and coordinate appropriately skilled onsite labor at the time they need them, the transportation to get their product off the farm, a close and available packing facility, delivery to the consumer, and the marketing of the product. In particular, Costello and Suarez (2015) document the increasing occurrence of labor shortages of trucker drivers during the important post-harvest delivery time. They find extensive regulations such as the difficult and expensive licensing procedure, expensive insurance, and a minimum age of 21 for interstate driving prevent wages from adjusting competitively. Highly restrictive regulations are also cited by Kidd and Padgett (2016) as a key issue preventing the post-harvest market from being competitive. Additional, though anecdotal, evidence of post-harvest labor shortages may be found in Morris (2015). Mongelluzzo (2015) reports on labor shortages in the warehousing sector.

The recognition of post-harvest labor shortages has led to work in the logistics field to estimate the costs of commodity loss along the transportation network. For example, Jessup and Herrington (2005) estimate the additional cost of shipping apples due to shortages of truck drivers by applying offseason rates to seasonal shipping volumes. Blackburn and Scudder (2009) find the critical period of product spoilage is between harvest and cooling or freezing. The length of this time period is largely determined by the availability-or lack thereof-of truck drivers. Bogataj et al. (2005) show that any 
change in time-distance (or temperature) in the supply chain could greatly affect the net present value of the commodity. Thus, delay in delivery of fresh horticultural products is an important aspect to consider.

\section{Methods}

\section{A two-good equilibrium displacement model with labor}

Our equilibrium displacement model is constructed using Muth (1964) as a foundation. The Muth model is a system of reduced-form equations of the competitive equilibrium of a single-good competitive industry and its associated competitive input markets. Nonprice shocks are applied to the model, which yields new competitive wages, employment, output quantity, and prices.

We expand the single good modeled in Muth to consider two goods in perfectly competitive markets: pome and prunus. These output markets are related to each other through nonsymmetric cross price elasticities of demand. Additionally, our model has two labor inputs, pre-harvest labor and post-harvest labor, partitioned by the activities they do in the production function. These input markets are competitive and partially related in the sense that workers in one labor market cannot easily transfer to the other labor market to seek higher wages. However, there is an outside option for each group so that labor of both types can move into and out of agricultural labor as determined by their labor supply elasticity. Because the focus is on labor markets, we do not explicitly model other inputs to production such as land, capital, or materials. The details of the model may be found in Appendix 1 .

The competitive equilibrium in the model occurs when output quantity and price for each commodity, pre-harvest labor wage and employment, and post-harvest labor wage and employment are such that the four markets clear. The parameters of the model are as follows:

1. The price elasticity of demand facing each industry $\left(\eta_{i}\right)$,

2. The cross price elasticity of demand facing each industry $\left(\kappa_{i j}\right)$,

3. The price elasticity of supply for each labor type $\left(e_{t}\right)$, and

4. The elasticity of substitution between pre- and post-harvest labor $(\sigma)$

where $i, j \in$ \{pome, prunus\} and $£ \in$ pre - harvest, post - harvest $\}$. There are also the following shock parameters:

5. The nonprice shift in demand for output of each industry $\left(\gamma_{i}\right)$,

6. The nonwage shift in labor supply of each type $\left(\alpha_{t}\right)$, and

7. The commodity-specific spoilage rate along the transportation network $\left(\xi_{i}\right)$.

Following Gunter et al. (1992), we implement our model in two stages. In the first stage, we calculate wage and employment changes in the pre- and post-harvest labor markets due to the two shocks. There is feedback from wage changes in the pre-harvest labor market to the post-harvest labor market (and vice versa) via the elasticity of substitution $\sigma$. In the second stage, the wages and employment from the two labor markets calculated in the first stage are entered into the producer's problem for the individual pome and prunus industries. This results in a calculation of the changes in output and price in the pome and prunus commodity markets. There is feedback 
from the price change in one output market on the other output market via the nonsymmetric cross price elasticity of demand $\kappa$. That $\kappa$ is not symmetric means that the sensitivity of demand of pome to price changes in the prunus market is not the same as the sensitivity of demand of prunus to price changes in the pome market $\left(\kappa_{i j} \neq \kappa_{j i}\right)$.

By using the two-stage approach of Gunter et al. (1992), we are assuming the pome and prunus industries are drawing pre-harvest labor from the same pre-harvest labor market and the pome and prunus industries are drawing post-harvest labor from the same post-harvest labor market. This is done because the labor markets facing each industry are quite similar in the sense that though there is no perfect substitutability between pre- and post-harvest labor within a market, there is essentially perfect substitutability of labor within activity types between the pome and prunus industries. For example, a truck driver can deliver either apples or peaches from the orchard to the packer but a picker cannot easily get a license to be a commercial truck driver.

The elasticity of substitution between pre-harvest and post-harvest labor, $\sigma$, is symmetric but does not apply to different occupations within type. That is, there is perfect mobility of pre-harvest labor between the pre-harvest tasks such as soil preparation, spraying, and picking and there is perfect mobility post-harvest labor between the post-harvest tasks such as marketing, packing, transportation, and distribution of the commodity. This elasticity measures how substitutable one type of labor is for doing the tasks of the other type of labor. For example, it would be as difficult for a picker to learn and get licensed to drive a large commercial truck hauling fresh fruit as it would be for an accountant to be a pre-harvest production manager. The elasticity of substitution of labor does not account for multi-product producers whose crop diversity means there are multiple harvest times throughout the year at a national level. However, as Fisher and Knutson (2013) argue, all of the producers in a local area are likely to have similar crop diversity and harvest times, thus creating local labor markets that are accounted for in the model.

We model the transportation and distribution network with a commodity-specific spoilage rate $\xi_{i}$. We incorporate the normal amount of spoilage into the pre-shock benchmark economy in the model. That commodity-specific spoilage rate is amplified when there is a post-harvest labor shortage because there are not enough truck drivers to ship and deliver produce without harmful delays. What we are suggesting is that due to driver shortages (or other laborers en route) the necessary transit time from harvest to market increases, and thus, output loss from spoilage also increases although there is no change in the labor market. A larger value of $\xi$ indicates more significant spoilage and thus less available output for sale relative to the zero-spoilage amount.

\section{Parameterization and shocks}

By giving the model values for the parameters, the equilibrium may be solved for uniquely. Table 1 shows the values used and the sources are discussed below.

Maintaining consistency with U.S. Department of Agriculture benchmarks, we use the values in Henneberry et al. (1999) for the price elasticity of demand for the pome and prunus industries. One difference between these industries is that consumer demand for pome is price inelastic but slightly price elastic for prunus. The price elasticity of demand for pome is -0.59 whereas it is -1.11 for prunus. Though the U.S. pome market has changed since the 1990s with the introduction of foreign apple 
Table 1 Parameters and shocks

\begin{tabular}{llr}
\hline Parameter & Description & Value \\
\hline$\eta_{\text {pome }}$ & Price elasticity of the industry demand for pome & $-0.59^{\text {a }}$ \\
$\eta_{\text {prunus }}$ & Price elasticity of the industry demand for prunus & $-1.11^{\text {a }}$ \\
$k_{\text {pome,prunus }}$ & Cross price elasticity of the industry demand for pome to prunus & $0.12^{\text {a }}$ \\
$k_{\text {prunus,pome }}$ & Cross price elasticity of the industry demand for prunus to pome & $0.02^{\text {a }}$ \\
$e_{\text {pre-harvest }}$ & Supply elasticity for pre-harvest labor input & $3.37^{\mathrm{b}}$ \\
$e_{\text {post-harvest }}$ & Supply elasticity for post-harvest labor input & $0.73^{\mathrm{c}}$ \\
$\sigma$ & Elasticity of substitution between pre-harvest labor and post-harvest labor input & $1.10^{\mathrm{d}}$ \\
$\gamma$ & Nonprice shift in demand for pome and prunus (demand shock) & $5.4 \%^{\mathrm{e}}$ \\
$a_{\text {pre-harvest }}$ & Nonwage shift in supply for pre-harvest labor (labor shock) & $-7.0 \%^{\mathrm{e}}$ \\
$\xi_{\text {pome }}$ & Spoilage rate for pome under normal conditions & $4.0 \%{ }^{f}$ \\
$\xi_{\text {prunus }}$ & Spoilage rate for prunus under normal conditions & $6.0 \%^{\mathrm{f}}$ \\
\hline
\end{tabular}

Sources: a Henneberry et al. (1999), berloff (1991), 'Duffield (1990), ${ }^{\mathrm{d} C}$ Card and Lemieux (2001), ${ }^{\mathrm{e}}$ Brady et al. (2016), and 'USDA NASS (various years)

varieties such as Gala, using much more recent data from 1998 to 2010, Okrent and Alston (2012) estimate the price elasticity of demand for apples to be an almost identical -0.60 . Thus, despite changes in market preferences for the types of pome, the price elasticity of demand has stayed nearly the same. We test the sensitivity of our results to this estimate in Appendix 2.

In the first stage of the model, we need the price elasticity of demand for the composite good of pome and prunus combined in order to see the effect on the aggregate pre-harvest and post-harvest labor markets from which both pome and prunus firms hire demand labor. We use a value of -0.67 , which is the weighted average of the price elasticities of demand of the two industries. That value is close to the -0.72 reported by the literature for the price elasticity of demand for all fruit.

We take the cross-price elasticities of demand from Henneberry et al. (1999) as well. The cross price elasticity for pome to changes in the price of prunus is 0.12 whereas it is 0.02 for prunus to changes in the price of pome. Though both are (weak) substitutes for each other, that these are asymmetric is another example of how the pome and prunus industries differ. Demand for pome is relatively more sensitive to price changes of prunus than prunus is for pome.

From Perloff (1991), we obtain the price elasticity of supply for pre-harvest labor. Perloff discusses the impact of wage differentials in choosing agricultural work. Based on a model of industry choice and wage determination, he estimates the quantity response of average agricultural unskilled labor to a $1.00 \%$ increase in the relative wage is $3.37 \%$. Perloff also estimates the likelihood of nonagricultural workers joining the agricultural work force in response to an increase in the agricultural wage. In Appendix 2, we test the robustness of our results to this parameter because of its uncertainty.

There does not seem to be a consensus estimate of the price (wage) elasticity of supply for post-harvest agricultural labor. This is perhaps not surprising as our research is among the first to consider post-harvest labor issues. We use the value from Duffield (1990). Using 40 years of data, he estimates the supply elasticity for hired farm labor to be 0.73 . As with the price elasticity of supply for pre-harvest labor, we test the robustness of our results to changes in this parameter in Appendix 2. 
Likewise, there are no estimates in the literature of the elasticity of substitution between pre- and post-harvest agricultural labor. Card and Lemieux (2001) find an elasticity of two between college educated and high school educated males. The elasticity needed for our model is likely to be lower as the tasks each group performs are different. A symmetric elasticity of substitution of 1.1 was chosen. As a robustness check, we report results using values of 0.7 and 1.5 as well. ${ }^{2}$

For the economic shocks, we set a 5.4\% outward shift of the demand curve for fresh produce. This value is from Brady et al. (2016). We also use the prediction from Brady et al. of a 7.0\% inward shift of the pre-harvest labor supply curve, which represents the decrease in the number of migrant workers. We shock the model simultaneously as Brady et al. predict each of these events will happen by 2021. We also shock the model by $2 \%, 5 \%$, and $11 \%$ for robustness. Those results may be found in Appendix 2 .

Our model is flexible enough to handle many different kinds of shocks. We choose to shock the model with a pre-harvest labor supply shock and output demand shock because Brady et al. gives us precise estimates for the size of those shocks. Thus, our results using those estimates are the most plausible and relevant to the industries under consideration. Though including both a demand and pre-harvest labor supply shock complicate the model to a degree, we feel it is important to consider the most realistic scenario rather than just studying the effects from a single shock.

\section{Data and the benchmark economy}

We use data on output prices and quantities as well as labor inputs and wages to calculate the benchmark economy. Wage and employment data are from the Occupational Employment Statistics Survey (OES) of the U.S. Department of Labor. ${ }^{3}$ These data are available at the occupation level. The occupation classification is hierarchical, meaning employment and wage data are provided at both the disaggregated level and the level of the parent category. For example, there are data for 11-0000 Management Occupations in the parent category and 11-1011 Chief Executives and 11-1021 General and Operations Managers in subcategories.

Employment in the data are all part-time and full-time workers who are paid a wage or salary. The data do not include the self-employed, owners, and partners in unincorporated firms, household workers, or unpaid family workers. We select the information in "Support Activities for Crop Production" (NAICS 115100). The OES does not further break down employment and wage data into specific commodities such as pome or prunus. Guided by economic theory about no arbitrage in competitive equilibrium, we assume that the wages for the same activities are equal for the pome and prunus industries. This assumption is the essence of the two-stage procedure to calculate changes to the equilibrium from the shocks applied to the model.

We further refine the employment and wage data by partitioning the occupations that would mainly take place pre-harvest and those that are considered to take place post-harvest or year-round at the occupation level. This partition is done using the occupation descriptions given in the OES. ${ }^{4}$ In most cases, all of the most disaggregated occupations within the same parent category are assigned to the same pre-harvest or post-harvest partition. Thus, we use the data provided for the parent category. For example, all of the 11-XXXX occupations are assigned to the post-harvest category and so we use the data provided by the 11-0000 major group. In only one case, that of 
51-0000 Production Occupations, do we assign some occupations to pre-harvest and others to post-harvest tasks. Thus, we use the data of the occupation-level subcategories for this case.

We collect data from 2002 through 2013 and then take the average across those 12 years to find a stable benchmark. Because we use the data of the parent category in most cases, the data are usually reported for the entire period. ${ }^{5}$ We add up the employments to get the total employment for all pre-harvest tasks and all post-harvest tasks. Next, we apply the share of fruit production to overall agricultural production and apply that ratio to the labor aggregates to get the amount of the total labor in the pome and prunus industries. Finally, we take the average across the years to get the benchmark employment in pre- and post-harvest labor for these industries.

We calculate the yearly weighted average wage of pre-harvest and post-harvest tasks by using the share of employment in each occupation as the weight. We deflate wages using the Consumer Price Index to 2013 dollar amounts and find the real average wage across the years.

Price and output data for apples and peaches are available from the USDA-ERS (various years). ${ }^{6}$ We use the data for total fresh fruit production delivered to consumers. We do not use data on production of canned or processed fruit products. We convert the nominal price data to real values using the CPI for fruits with 2013 as the base year. As with the labor markets, we average the real prices and quantities to produce aggregate values.

We obtain information on the typical amount of spoilage for pome and prunus from the ERS Fruit and Tree Nut Year Book (2014). The information indicates the spoilage rate of pome reduces value by $4 \%$ under normal conditions. The spoilage rate of prunus reduces value by $6 \%$. Thus, prunus spoils $33 \%$ more than pome. These rates are built into our benchmark economy.

Table 2 shows the summary statistics for employment, wages, production, and prices by commodity. One key point to notice in Table 2 is that the size of the pre-harvest labor force is about three times larger than the post-harvest labor force. Yet wages for post-harvest workers are about 33\% larger than those for pre-harvest workers. Another key point is that pome production is six to seven times larger than prunus production. However, the prunus retail price exceeds the pome retail price by more than $30 \%$.

Table 2 Summary statistics

\begin{tabular}{lrrrr}
\hline Variable & Mean & Std. dev. & \multicolumn{1}{c}{ Min. } & Max. \\
\hline Pre-harvest employment (thousands) & 36.07 & 4.84 & 30.01 & 43.74 \\
Post-harvest employment (thousands) & 11.75 & 1.59 & 9.87 & 15.07 \\
Pre-harvest weighted real wage (\$/hour) & 11.64 & 0.62 & 12.64 & 10.55 \\
Post-harvest weighted real wage (\$/hour) & 15.71 & 1.13 & 17.37 & 13.78 \\
Pome production (million lbs) & 6126.45 & 1075.44 & 5633.00 & 6886.90 \\
Prunus production (million lbs) & 932.15 & 201.31 & 789.80 & 1074.50 \\
Pome real retail price (\$/lbs) & 1.24 & 0.12 & 1.16 & 1.33 \\
Prunus real retail price $(\$ /$ lbs) & 1.69 & 0.17 & 1.57 & 1.82 \\
\hline
\end{tabular}

Note: Entries are the statistics for the yearly average from 2002 to 2013

Source: U.S. Dept. of Labor OES (2014) and U.S. Dept. of Agricultural ERS Fruit and Tree Nut Year Book (2014). Real values are calculated using 2013 as base year 
To calculate the differences in the pre- and post-shock equilibria, we need the slope of the post-harvest labor demand curve. We calculate this by first averaging the data on real wage and employment from post-harvest occupations in 2002 and 2013. Then, we assume the variation in the data was caused by shifts in the supply of the labor curve. From that assumption, the calculated slope of the post-harvest labor demand curve is -0.0057 .

\section{Results and discussion}

\section{Competitive equilibrium pre- and post-shock}

We first have the model calculate the pre-shock competitive equilibrium to match the data from Table 2. That is seen in Fig. 1, which displays the pome and prunus output markets as well as the pre-harvest and post-harvest labor markets. The pre-shock competitive equilibrium is designated E1. Note the demand curve in the pome market is more price inelastic at -0.59 than the prunus market at -1.11 . There is not a labor shortage in either the pre- or post-harvest labor markets. The competitive wage is $\$ 11.64$ for pre-harvest labor and $\$ 15.70$ for post-harvest labor. Total employment is 36,071 for pre-harvest labor and 11,748 for post-harvest labor. The price of pome is $\$ 1.24$ and quantity sold is 6.13 billion pounds whereas price is $\$ 1.69$ for prunus and 0.932 billion pounds are sold. ${ }^{7}$

Next, we shock the model with a $5.4 \%$ increase in output demand for both pome and prunus from population growth. This is seen in Fig. 1 with $D^{\prime}$ and the new

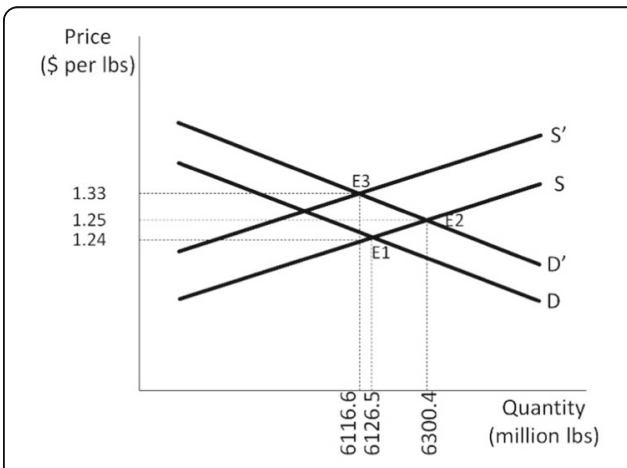

(a) Pome market

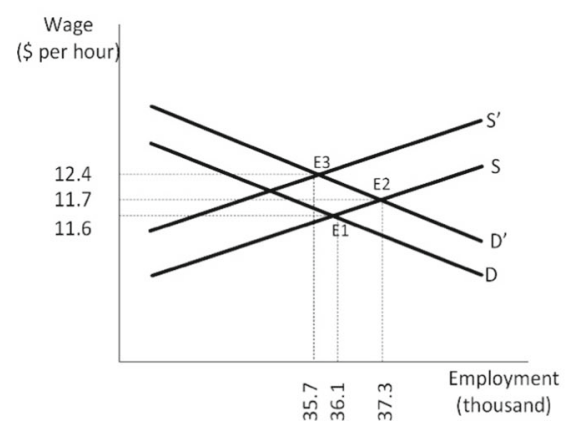

(c) Pre-harvest labor market

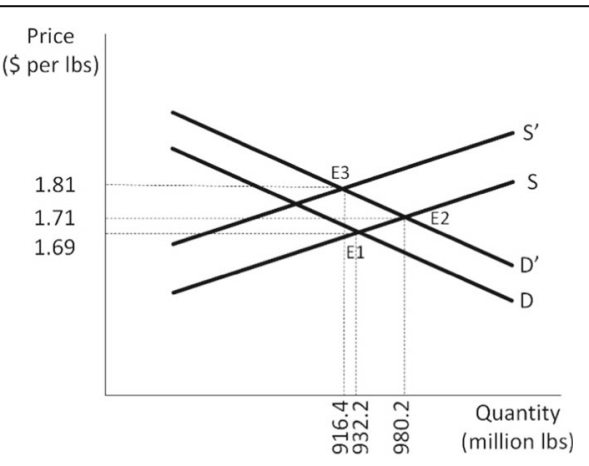

(b) Prunus market

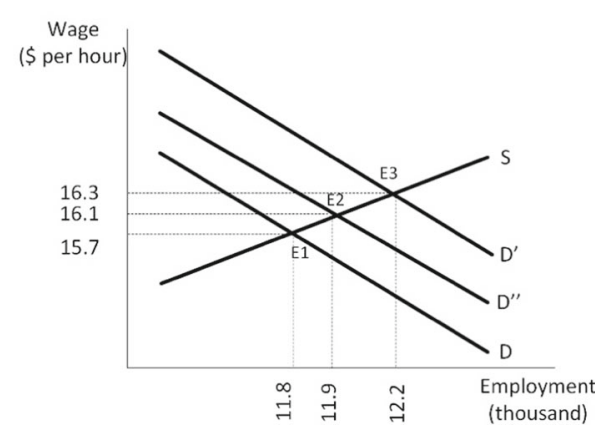

(d) Post-harvest labor market

Fig. 1 Illustrative example of pre-shock and post-shock competetive equilibrium for a pome, b prunus, c pre-harvest labor, and $\mathbf{d}$ post-harvest labor markets 
equilibrium is designated by E2. Note that the shifting out of the demand curve is direct for the pome (a) and prunus (b) output markets, but it is indirect in the pre-harvest (c) and post-harvest (d) labor input markets. That is, because of the increase in demand for output, producers demand more labor for each wage rate, and thus $D^{\prime}$ shifts out compared to D in the input markets.

At the same time, we shock the model with a $7 \%$ decrease in the supply of pre-harvest labor. This is seen in Fig. 1 as $S^{\prime}$ to the left of $S$ in panel (c) and the new equilibrium is designated E3. The resulting post-shock competitive equilibrium has a higher wage for pre-harvest labor. That means the costs of production of pome and prunus increases and thus $S^{\prime}$ shifts to the left and is higher than $S$ in panels (a) and (b). Producers respond to the increase in pre-harvest wage by reducing pre-harvest labor employment from 36,071 to 35,768 in the post-shock competitive equilibrium.

Because there is a decrease in pre-harvest employment, there is also a decrease in output for both the pome and prunus industries at the E3 competitive equilibrium compared to E1. Because there is less output, producers hire fewer post-harvest workers. However, the substitution effect causes hiring of post-harvest workers, which is seen by $D^{\prime \prime}$ being to the right of $D^{\prime}$. The amount of post-harvest employment increases in E3 compared to E1 because though output is decreasing, producers are trying to make up for the loss of pre-harvest labor by substituting with post-harvest labor. However, with $\sigma=1.1$, firms cannot readily replace pre-harvest workers with post-harvest workers. The end result is that pre-harvest wages increase $6.28 \%$ or $\$ 0.78$ per hour and pre-harvest employment falls $0.60 \%$ and $2.08 \%$ for the pome and prunus industries, respectively. Post-harvest wages increase $3.48 \%$ or $\$ 0.55$ to $\$ 16.25$ per hour. Neither the pre- nor post-harvest labor markets experience a labor shortage as the wage adjusts to prevent this. Since our main results compare the post-shock competitive equilibrium to the post-shock fixed wage scenario, we relegate the detailed results comparing the pre-shock competitive equilibrium to the post-shock competitive equilibrium to Table 8 in Appendix 2 for percent change and Table 9 in Appendix 2 for change in levels.

\section{Post-shock equilibrium and fixed wage labor shortage outcome}

In order to compare the competitive equilibrium outcome against an outcome with labor shortages, we exogenously impose that wages in the pre- and post-harvest markets are fixed at the benchmark level of the pre-shock equilibrium E1. This comparative static is appropriate because of the evidence provided in the section "Labor Shortages and Fixed Wages" that wages do not fully adjust to shocks in either the pre-harvest or post-harvest markets. Because we fix wages at the pre-shock competitive level, our results reflect the upper bound as any partial wage adjustment would reduce our quantitative, but not qualitative, results.

Figure 2 shows the pome and prunus output markets and the pre- and post-harvest labor input markets when $\sigma=1$.1. In panel (c), the number of employed pre-harvest workers decreases more than the decrease in the competitive equilibrium scenario because there is no increase in wage to induce additional pre-harvest workers to enter the market. We estimate the amount of pre-harvest labor employed in the pome and 


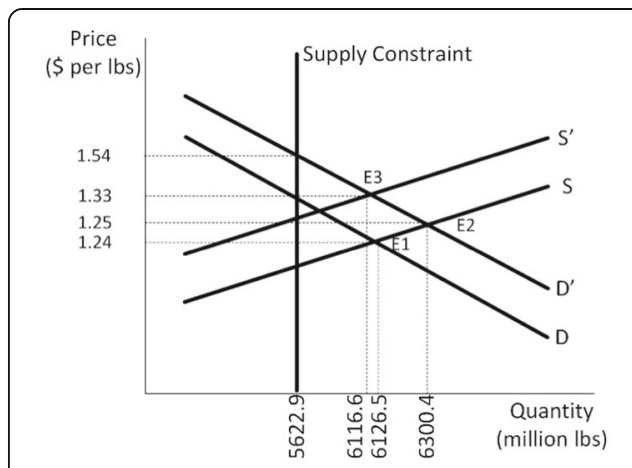

(a) Pome market

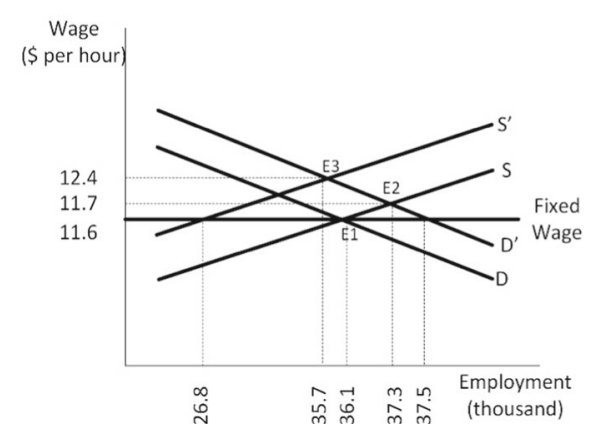

(c) Pre-harvest labor market

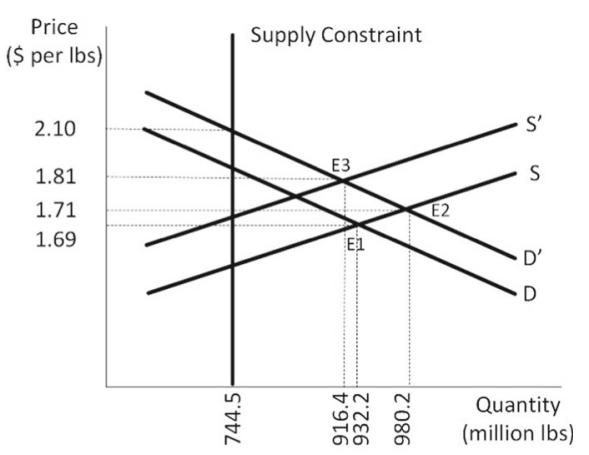

(b) Prunus market

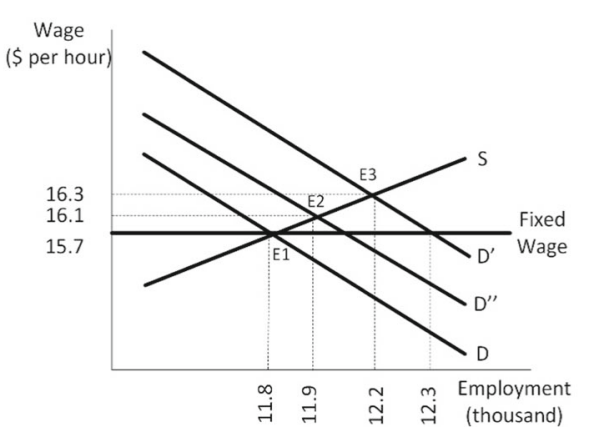

(d) Post-harvest labor market

Fig. 2 Illustrative example of post-shock fixed wage scenario for a pome, b prunus, c pre-harvest labor, and d post-harvest labor markets

prunus industry decreases from 36,071 to 26,754 if the wage remains at the initial level of $\$ 11.64$ whereas employment would only fall to 35,768 if the competitive wage were offered at $\$ 12.42$. Because of the increase in final demand, however, the derived demand for pre-harvest labor shifts out to $D^{\prime}$ from $\mathrm{D}$ in panel (c). This means that though employment has dropped from 36,071 to 26,754 , the industry wishes to employ 37,536 workers at a wage of $\$ 11.64$. Thus, the predicted pre-harvest labor shortage in the pome and prunus market is 10,782 or about $30 \%$ of the pre-shock level of employment.

The pome and prunus industries would like to use more post-harvest labor to at least partially offset the reduction in pre-harvest labor. However, with the wage for post-harvest labor fixed at $\$ 15.71$, no additional post-harvest workers agree to work as seen in panel (d). Firms wish to increase post-harvest labor employment from 11,748 to 12,266 , thus creating a post-harvest labor shortage of 518 workers or $4.4 \%$ of the pre-shock level of employment.

Because firms cannot hire additional post-harvest labor, the full brunt of the shocks is passed through onto production and is realized as a supply constraint in the output market. That can be seen in panel (a) and (b) as the supply constraint created by the labor shortages is well below the competitive equilibrium amount of output. For the pome industry, the shortfall is 493.8 million lbs from the post-shock competitive level. The sales price increases to $\$ 1.54$ per pound from the $\$ 1.33$ per pound post-shock competitive price, an increase of about $16 \%$. Thus, the labor shortages are causing a 
Table 3 Post-shock equilibrium and fixed wage outcome percent change

\begin{tabular}{ccccccc}
\hline$\sigma$ & $\begin{array}{c}\text { Output } \\
\text { (Percent change) }\end{array}$ & Price & Pre emp. & Pre wage & Post emp. & Post wage \\
\hline $\begin{array}{llllll}\text { Pome } \\
0.7\end{array}$ & & & & & \\
1.1 & -8.49 & 16.80 & -22.64 & -6.73 & -2.89 & -2.66 \\
1.5 & -8.07 & 15.93 & -22.37 & -6.70 & -3.69 & -3.48 \\
Prunus & -7.06 & 13.96 & -22.06 & -6.68 & -4.21 & -4.01 \\
0.7 & -19.66 & 16.52 & -40.80 & -6.73 & -0.72 & -2.66 \\
1.1 & -18.76 & 15.79 & -40.00 & -6.70 & -2.31 & -3.48 \\
1.5 & -16.39 & 13.82 & -39.29 & -6.68 & -3.81 & -4.01 \\
\hline
\end{tabular}

price premium of $\$ 0.21$ per pound. For the prunus industry, the shortfall is 171.9 million lbs and an increase in price to $\$ 2.10$ per pound from $\$ 1.81$ per pound post-shock, an increase of about $16 \%$. Because the price of pome and prunus both increase by about $16 \%$, the impact of the price increase on the demand for the other commodity is negligible.

Table 3 shows the percent changes, and Table 4 shows the level changes from the post-shock competitive equilibrium to the post-shock scenario with fixed wages. We report the results for our preferred benchmark with $\sigma=1.1$ as well as when we vary $\sigma$. It becomes increasingly difficult to substitute labor across activities from $\sigma$ of 1.5 to 0.7. Thus, the impact of the fixed wage on output and price becomes larger as $\sigma$ decreases because the industries cannot adjust by changing the employment composition as easily.

Because firms are less able to adjust to the shocks from changing the labor composition, $D^{\prime}$ shifts out less far in the pre-harvest market and $D^{\prime \prime}$ shifts in more in the post-harvest market when $\sigma=0.7$ than when $\sigma=1.5$. Thus, there is a smaller drop in post-harvest wage and employment in the fixed wage outcome compared to the competitive equilibrium when the elasticity of substation is smaller. Nonetheless, the fixed wage scenario and labor shortages lead to an outcome with substantially less output, higher prices, and lower employment than the post-shock competitive equilibrium outcome regardless of the value of $\sigma$.

Table 4 Post-shock equilibrium and fixed wage outcome level change

\begin{tabular}{|c|c|c|c|c|c|c|}
\hline $\bar{\sigma}$ & $\begin{array}{l}\text { Output } \\
\text { (mil. Lbs) }\end{array}$ & $\begin{array}{l}\text { Price } \\
(\$ / \mid \mathrm{bs})\end{array}$ & $\begin{array}{l}\text { Pre emp. } \\
\text { (ones) }\end{array}$ & $\begin{array}{l}\text { Pre wage } \\
(\$ / h)\end{array}$ & $\begin{array}{l}\text { Post emp. } \\
\text { (ones) }\end{array}$ & $\begin{array}{l}\text { Post wage } \\
(\$ / h)\end{array}$ \\
\hline \multicolumn{7}{|l|}{ Pome } \\
\hline 0.7 & -518.91 & 0.22 & -6798.17 & -0.78 & -292.88 & -0.42 \\
\hline 1.1 & -493.79 & 0.21 & -6715.73 & -0.78 & -376.42 & -0.55 \\
\hline 1.5 & -431.91 & 0.19 & -6622.90 & -0.78 & -431.46 & -0.63 \\
\hline \multicolumn{7}{|c|}{ Prunus } \\
\hline 0.7 & -179.90 & 0.30 & -2343.16 & -0.78 & -14.02 & -0.42 \\
\hline 1.1 & -171.89 & 0.29 & -2298.44 & -0.78 & -45.32 & -0.55 \\
\hline 1.5 & -150.36 & 0.25 & -2258.15 & -0.78 & -76.04 & -0.63 \\
\hline
\end{tabular}

Notes: $e_{\mathrm{s}}=0.73, e_{\mathrm{u}}=3.37,5.4 \%$ final demand shock, and $-7 \%$ pre-harvest labor supply shock 


\section{Post-shock fixed wage with transportation and spoilage}

Timely delivery of produce to market is important and thus the effects on the transportation network from a post-harvest labor shortage should be considered. Because our model cannot determine how much a $4.4 \%$ post-harvest labor shortage will increase the spoilage rate, we instead calculate what the spoilage rate would have to be in order for producers to be more harmed than the post-shock competitive equilibrium in E3. An increase in the spoilage rate exacerbates the reduction in sales though the amount of output, and thus employment, remains the same. At some point, the reduction in sales begins to harm producers more than the increase in price benefits producers. That is the spoilage rate we use in our calculations.

The results, available in Table 5 as percent changes and Table 6 as level changes, compare the post-shock competitive equilibrium to the post-shock outcome with fixed wages and the effects of spoilage along the transportation network. The results are directly comparable to Table 3 and Table 4 . The harm to the prunus industry compared to the fixed wage outcome begins immediately. But the prunus industry is not harmed compared to the competitive equilibrium until the spoilage rate is $26 \%$. The pome industry is not harmed compared to the competitive equilibrium until the spoilage rate is $56 \%$. Thus, the pome industry can withstand labor-shortage-induced spoilage much better than the prunus industry.

The effect of the transportation network is felt in the output markets. In the pome industry, the massive spoilage rate greatly reduces output to only $40 \%$ of the competitive output, down from $92 \%$ without spoilage. The price skyrockets to $117 \%$ of the competitive price from $16 \%$ when there is a fixed wage. The prunus industry experiences an increase in price of $33.87 \%$ from $15.79 \%$. Output decreases by $40.2 \%$ from the competitive equilibrium, much lower than the $18.8 \%$ decrease in the fixed wage scenario.

The difference in the outcomes of the pome and prunus markets is due to the larger size of the pome industry and the smaller price elasticity of demand facing the pome industry.

Pome is price inelastic. An additional increase in price from the spoilage rate offsets the further loss in output in terms of revenue. The opposite is true for prunus, which is price elastic. Thus, prunus industry revenue suffers from any amount of spoilage. This would be true even if the spoilage rate for pome and prunus is the same, but since

Table 5 Post-shock and fixed wage and transportation effect percent change

\begin{tabular}{ccccccc}
\hline $\begin{array}{l}\text { O Output } \\
\text { (Percent change) }\end{array}$ & Price & Pre emp. & Pre wage & Post emp. & Post wage \\
\hline $\begin{array}{c}\text { Pome } \\
0.7\end{array}$ & -59.54 & 117.82 & -22.64 & -6.73 & -2.89 & -2.66 \\
1.1 & -59.09 & 116.60 & -22.37 & -6.70 & -3.69 & -3.48 \\
1.5 & -60.52 & 119.70 & -22.06 & -6.68 & -4.21 & -4.01 \\
Prunus & & & & & & \\
0.7 & -41.29 & 34.70 & -40.80 & -6.73 & -0.72 & -2.66 \\
1.1 & -40.22 & 33.87 & -40.00 & -6.70 & -2.31 & -3.48 \\
1.5 & -42.48 & 35.83 & -39.29 & -6.68 & -3.81 & -4.01 \\
\hline
\end{tabular}


Table 6 Post-shock and fixed wage and transportation effect level change

\begin{tabular}{|c|c|c|c|c|c|c|}
\hline$\sigma$ & $\begin{array}{l}\text { Output } \\
\text { (mil. Lbs) }\end{array}$ & $\begin{array}{l}\text { Price } \\
(\$ / \mid \mathrm{bs})\end{array}$ & $\begin{array}{l}\text { Pre emp. } \\
\text { (ones) }\end{array}$ & $\begin{array}{l}\text { Pre wage } \\
(\$ / h)\end{array}$ & $\begin{array}{l}\text { Post emp. } \\
\text { (ones) }\end{array}$ & $\begin{array}{l}\text { Post wage } \\
(\$ / h)\end{array}$ \\
\hline \multicolumn{7}{|c|}{ Pome } \\
\hline 0.7 & -3639.94 & 0.22 & -6798.17 & -0.78 & -292.88 & -0.42 \\
\hline 1.1 & -3614.52 & 0.21 & -6715.73 & -0.78 & -376.42 & -0.55 \\
\hline 1.5 & -3703.18 & 0.19 & -6622.90 & -0.78 & -431.46 & -0.63 \\
\hline \multicolumn{7}{|c|}{ Prunus } \\
\hline 0.7 & -377.84 & 0.63 & -2343.16 & -0.78 & -14.02 & -0.42 \\
\hline 1.1 & -368.61 & 0.61 & -2298.44 & -0.78 & -45.32 & -0.55 \\
\hline 1.5 & -389.64 & 0.65 & -2258.15 & -0.78 & -76.04 & -0.63 \\
\hline
\end{tabular}

there is a greater loss from spoilage for prunus, it makes that industry more vulnerable to post-harvest labor shortages.

Because we fix the wage at the level of the pre-shock competitive equilibrium, these results should be considered an upper estimate. To the extent that wages adjust somewhat, our quantitative results will reflect that adjustment, though our qualitative results hold. In addition, we do not model a world price of pome and prunus, which may drastically decrease the ability of these industries to pass-though the spoilage rate costs onto the consumer as higher prices, and thus harm would come at much lower spoilage rates. In that case, increased imports would maintain the quantity consumed and prevent prices from increasing; thus, the loss to consumer welfare would be limited. Instead, losses would fall most directly on domestic producers. Harm would come to domestic producers much more quickly than the spoilage rates we report. Finally, our analysis is limited to the industry level because of data unavailability. Despite this limitation, the lessons here can be applied to differentiated sub-industry products such as particular varieties or organically produced products, for example.

\section{Welfare comparisons}

Because wages are flexible in the post-shock competitive equilibrium, the labor markets clear and there are no labor shortages. When the wage is fixed, however, the labor markets do not clear. Thus, there are labor shortages, deadweight loss, and economic inefficiency. The labor shortages create a supply constraint in the output markets and prevent those markets from clearing. Thus, there is deadweight loss in those markets as well.

Table 7 shows the surplus changes associated with the labor shortages, comparing the post-shock competitive equilibrium to the post-shock fixed wage outcome. As can be seen, consumers are harmed in terms of lost economic welfare. Consumers lose \$1244.6 million in the pome market and an additional \$237.7 million in the prunus market from the combination of the increase in output price and decrease in output available for consumption. Pre-harvest and post-harvest labor experience decreases in welfare as well, as the wage is lower than in competitive 
Table 7 Economic surplus

\begin{tabular}{|c|c|c|c|c|c|}
\hline & $\begin{array}{l}\text { Post-shock competitive } \\
\text { equilibrium }\end{array}$ & $\begin{array}{l}\text { Post-shock } \\
\text { fixed wage }\end{array}$ & $\begin{array}{l}\text { Welfare } \\
\text { change }\end{array}$ & $\begin{array}{l}\text { Post-shock fixed } \\
\text { wage transport }\end{array}$ & $\begin{array}{l}\text { Welfare change } \\
\text { transport }\end{array}$ \\
\hline \multicolumn{6}{|c|}{ Pome commodity market (million \$) } \\
\hline Consumer & 8032.6 & 6788.0 & -1244.6 & 1344.1 & -6688.4 \\
\hline Firm & 1002.2 & 2187.9 & 1186.7 & 1002.2 & 0.0 \\
\hline Total & 9034.8 & 8975.9 & -58.9 & 2346.4 & -6688.4 \\
\hline \multicolumn{6}{|c|}{ Prunus commodity market (million \$) } \\
\hline Consumer & 699.2 & 461.5 & -237.7 & 249.8 & -449.3 \\
\hline Firm & 113.8 & 322.9 & 209.1 & 113.8 & 0.0 \\
\hline Total & 813.0 & 784.4 & -28.6 & 363.6 & -449.3 \\
\hline \multicolumn{6}{|c|}{ Pre-harvest labor market (million \$) } \\
\hline Pre-harvest labor & 110.7 & 61.9 & -48.8 & 61.9 & -48.8 \\
\hline Firm & 564.4 & 570.3 & 5.9 & 570.3 & 5.9 \\
\hline Total & 675.1 & 632.2 & -42.9 & 632.2 & -42.9 \\
\hline \multicolumn{6}{|c|}{ Post-harvest labor market (million \$) } \\
\hline Post-harvest labor & 253.6 & 237.6 & -16.0 & 237.6 & -16.0 \\
\hline Firms & 842.1 & 856.8 & 14.7 & 856.8 & 14.7 \\
\hline Total & 1095.7 & 1094.4 & -1.2 & 1094.4 & -1.2 \\
\hline \multicolumn{6}{|l|}{ Total firms (million \$) } \\
\hline Total pome firms & 2179.3 & 3382.2 & 1202.9 & 2196.5 & 17.2 \\
\hline Total prunus firms & 343.3 & 555.7 & 212.4 & 346.6 & 3.4 \\
\hline
\end{tabular}

Notes: Surplus in labor markets is calculated by multiplying the estimated equilibrium wage times the average number of workers in each occupation that each industry uses, less the opportunity cost of labor as indicated by the labor supply curve, and then adjusting for $40 \mathrm{~h}$ per week for 50 weeks per year. Total firms surplus (not profit) is the sum of surplus from the specific commodity market plus the welfare from the pre-harvest and post-harvest labor markets determined by the ratio of industry employment to total employment for each activity type. Values are for 2013

equilibrium and employment decreases. Pre-harvest labor experiences a welfare loss of $\$ 48.8$ million and post-harvest labor experiences a welfare loss of $\$ 16.0$ million.

On the other hand, there are large gains to producers' welfare with the wage fixed at the pre-shock level. ${ }^{8}$ Though there is a labor shortage, the benefit to firms from paying a lower wage is greater than the cost of not producing and selling as much because they are able to obtain a price premium on the reduced output. Firms benefit in both the pome and prunus markets because firms are able to capture much of the lost consumer welfare from the competitive outcome. The gain to pome firms is $\$ 1185.7$ million from just the output market, and the gain to prunus firms is $\$ 209.1$ million from just the output market. When the gains to producers from the labor markets are included, the pome and prunus producers increase welfare by $\$ 1202.9$ million and $\$ 212.4$ million, respectively. Note, however, that the gains to producer welfare are almost exclusively due to obtaining a wage-rigidity-induced price premium, not from paying a lower than competitive wage. Only about $1.5 \%$ of the surplus to pome and prunus firms comes from the labor markets.

Despite the gain to producers, the fixed wage outcome is economically inefficient. Deadweight loss is $\$ 58.9$ million in the pome market, $\$ 28.6$ million in the prunus 
market, \$42.9 million in the pre-harvest labor market, and \$1.2 million in the post-harvest labor market as measured in 2013 dollars. Thus, there are significant costs to the economy from the labor shortages.

The right most column in Table 7 is the comparison in welfare from the post-shock competitive equilibrium to the post-shock fixed wage when spoilage is set to be $26 \%$ for prunus and $56 \%$ for pome. That scenario is constructed so that producer welfare is equal to that in the competitive equilibrium. There are huge losses to consumers in this case, coming from large increases in price and a decrease in output available for purchase. Because wages and employment do not change for pre-harvest and post-harvest labor with transportation compared to without, the welfare for the pre- and post-harvest labor markets are the same in both fixed wage scenarios.

\section{Conclusion}

Labor shortages in agricultural production have the attention of scholars, industry representatives, and the public alike. Unlike the production literature, we partition labor markets into pre-harvest and post-harvest to focus on how the economic impacts of a pre-harvest labor shortage affect the post-harvest labor markets and downstream commodity output markets. We explicitly consider how post-harvest labor shortages exacerbate time for produce delivery by modeling the transportation network via a spoilage rate as a productivity parameter. We use data from the U.S. pome (apple) and prunus (peach) industries because their large size and wide geographic spread make them representatives for the overall agricultural sector.

After shocking the economy with a predicted $5.4 \%$ increase in output demand and a $7.0 \%$ decrease in pre-harvest labor supply, we compare the outcomes where wages are perfectly flexible to a scenario where wages are fixed at the pre-shock level. The shocks create pressure for pre-harvest and post-harvest wages to increase, but when wages are fixed, the industries must adjust by reducing employment. That creates labor shortages reaching $30 \%$ of the pre-shock employment for pre-harvest labor and $4.4 \%$ for post-harvest labor. The reduced employment also reduces output and creates a $16 \%$ price premium over the competitive price. The prunus market is less able to adjust as its relatively price-elastic demand causes consumers to react to the price increase by switching to pome.

The labor shortages inefficiently distort the markets, creating deadweight loss. These surplus losses are $\$ 87.5$ million in the output markets and $\$ 44.1$ million in the labor markets in 2013 dollars. But, we find losses are borne by consumers and labor. Producer surplus sizably increases in both the pome and prunus industry almost exclusively as a result of the benefits of the price premium outweighing the decrease in sales volume. Thus, if output prices could not increase so readily, the gains to firms would be dramatically limited or negative. For example, foreign competition may not allow domestic firms to pass-through a price premium of the size estimated here. When the effects of additional spoilage along the transportation network from the post-harvest labor shortage are 
considered, the prunus industry is at much greater risk than the pome industry. This is because prunus is more price elastic and more sensitive to time delays in delivery.

If the predictions from Brady et al. (2016) are accurate, then the agricultural industries whose demand is the most price sensitive, whose spoilage rates are fastest, or that have the weakest transportation network will be the most affected. Economic losses can be large relative to the size of the industry, with pre-harvest labor, post-harvest labor, and consumers all suffering. Though we do not explicitly model time dynamics or international competition, it is not beyond the realm of plausibility to speculate the additional cost to consumers from these labor shortages could damage the marketability of U.S. produce domestically as well as in overseas markets and also allow for the entry of foreign competition. Additionally, we believe that the lessons learned (if not the values) from the differential impacts to the pome and prunus industry could be applied to sub-markets that for reasons of data unavailability we could not model: for example, the different varieties of apples, or organic vs. traditional products, and fresh vs. processed and frozen products.

\section{Endnotes}

${ }^{1}$ Though we differentiate between the pome and prunus industries, data limitations prevent us from modeling sub-industries such as different apple varietals or organic versus traditionally produced products. Though certainly a limitation, we believe the lessons learned from the two industries we are able to model may be applied qualitatively to sub-market products.

${ }^{2}$ A value of 1.1 is the lowest of the several estimates Card and Lemieux (2001) report. An elasticity of substitution of 0.7 indicates complements in labor inputs rather than the weak substitutes we report in our main results. Though using a value such as 0.7 means the derived demand for post-harvest labor decreases with pre-harvest labor, our qualitative results remain. Thus, our qualitative results are robust to whether pre-harvest and post-harvest tasks (and their associated labor) are substitutes or complements in production.

${ }^{3} \mathrm{http}: / /$ www.bls.gov/oes/tables.htm.

${ }^{4}$ In the case of an establishment that is both a farm and a packing house, the packing employees should be counted in the OES.

${ }^{5}$ For Production Occupations, there are some instances of missing employment and wage data. To estimate missing employment in a particular year and occupation, we first use the linear combination of the reported data on the years surrounding it. Next, we compare the sum of the occupations at the disaggregated level to the data reported at the parent level. We then make adjustments to the estimates from the first step in order to not exceed the adding-up constraint provided by the parent-level data. The employment for the missing estimates is then refined until the sum of the disaggregated occupation employments in within 95 to $100 \%$ of the reported employment in the parent category. For missing wage data, we use the linear combination of the observations surrounding the missing datum. 
${ }^{6}$ http://www.ers.usda.gov/data-products/fruit-and-tree-nut-data/yearbook-tables.aspx\#40907.

${ }^{7}$ All values are rounded for convenience in exposition, which may cause some values to not sum to their total. Figure 1 is for illustrative purposes and not meant to be the literal representation of the markets.

${ }^{8}$ Producer welfare is conceptually different from industry profit and can include rents to inputs not explicitly modeled, accounting for why producer surplus is not zero even in the case of perfect competition.

\section{Appendix 1}

\section{Two-stage Muth model}

We adopt Muth's (1964) model to analyze the effects of input supply shifts on industry output and input prices and quantities. Following Muth's model, we assume a representative producer of a homogeneous product using two inputs. The difference from Muth is that our inputs are pre-harvest and post-harvest labor. The producer is a price taker in the output and input markets. Under these conditions, the equilibrium of the industry may be described by the following equations:

$$
\begin{aligned}
& Q=f(p) \quad \#(A .1) \\
& Q=Q\left(L_{u}, L_{s}\right) \quad \#(A .2) \\
& w_{u}=p q_{u} \quad \#(A .3) \\
& w_{s}=p q_{s} \quad \#(A .4) \\
& L_{u}=g\left(w_{u}\right) \quad \#(A .5) \\
& L_{s}=h\left(w_{s}\right) \quad \#(A .6)
\end{aligned}
$$

where $Q$ is the final output of the commodity, the price per unit of the final product is $p, L_{u}$ and $L_{s}$ are pre-harvest labor and post-harvest labor inputs, the factor prices are $w_{u}$ and $w_{s}$, and the marginal product of labor by activity type is given by $q_{u}$ and $q_{s}$. Equation (A.1) is demand for the industry's output, and (A.2) is the production function. Wages are given by the marginal product of each type of labor input as in (A.3) and (A.4). Finally, the factor supply facing the industry is given by (A.5) and (A.6).

By totally differentiating, we get:

$$
\begin{aligned}
& -\frac{1}{\eta} \partial \ln Q+\partial \ln p=\gamma \\
& \partial \ln Q-l_{u} \partial \ln L_{u}-l_{s} \partial \ln L_{s}=\delta \\
& -\partial \ln p+\frac{l_{u}}{\sigma} \partial \ln L_{s}-\frac{l_{s}}{\sigma} \partial \ln L_{u}+\partial \ln w_{s}=\delta+\varepsilon \\
& -\partial \ln p-\frac{l_{s}}{\sigma} \partial \ln L_{s}+\frac{l_{s}}{\sigma} \partial \ln L_{u}+\partial \ln w_{u}=\delta-\frac{l_{s}}{l_{u}} \varepsilon \\
& -\frac{1}{e_{u}} \partial \ln L_{u}+\partial \ln w_{u}=\alpha_{u} \\
& -\frac{1}{e_{s}} \partial \ln L_{s}+\partial \ln w_{s}=\alpha_{s}
\end{aligned}
$$


where $\eta$ is the price elasticity of the industry demand, $\gamma$ is the relative increase in price at any given quantity on the new demand schedule (demand shift), $l_{u}$ and $l_{s}$ are the proportion of total receipts that are assigned to pre-harvest labor input and post-harvest labor input, $\sigma$ is the elasticity of substitution between pre-harvest labor input and postharvest labor input, $\delta$ is the factor-neutral productivity shift, $E$ shifts pre-harvest labor from a productivity shock, $e_{u}$ and $e_{s}$ are the price (wage) elasticities of pre-harvest labor supply and post-harvest labor supply, and $\alpha_{u}$ and $\alpha_{s}$ are the pre-harvest labor supply shift and post-harvest labor supply shift terms from a nontechnological change.

By adding a second output, the solution becomes:

$$
\begin{aligned}
& Q^{i}=f\left(p^{i}, p^{j}\right) \quad \#(A .7) \\
& Q^{i}=Q\left(L_{u}^{i}, L_{s}^{i}\right) \quad \#(A .8) \\
& w_{u}=p^{i} q_{u}^{i} \#(A .9) \\
& w_{s}=p^{i} q_{s}^{i} \quad \#(A .10)
\end{aligned}
$$

where $i$ and $j$ denote the commodities. Equilibrium wages are equal within activity types across commodities. The aggregate labor clearing conditions (A.5) and (A.6) remain as before. Total logarithmic differentiation of (A.7) through (A.10) gives:

$$
\begin{aligned}
& -\partial \ln p^{i}+\frac{l_{u}^{i}}{\sigma} \partial \ln L_{s}^{i}-\frac{l_{s}^{i}}{\sigma} \partial \ln L_{u}^{i}=\delta^{i}+\varepsilon^{i}-\partial \ln w_{s} \\
& -\partial \ln p^{i}-\frac{l_{s}^{i}}{\sigma} \partial \ln L_{s}^{i}+\frac{l_{s}^{i}}{\sigma} \partial \ln L_{u}^{i}=\delta-\frac{l_{s}^{i}}{l_{u}^{i}} \varepsilon^{i}-\partial \ln w_{u} \\
& -\frac{1}{\eta^{i}} \partial \ln Q^{i}+\partial \ln p^{i}+\frac{\kappa^{i j}}{\eta^{i}} \partial \ln p^{j}=\gamma^{i} \\
& \partial \ln Q^{i}-l_{u}^{i} \partial \ln L_{u}^{i}-l_{s}^{i} \partial \ln L_{s}^{i}=\delta^{i}
\end{aligned}
$$

where $\kappa_{i j}$ is the asymmetric cross price elasticity for commodity $i$ in response to a change in price of commodity $j$ and $\sigma$ is the symmetric elasticity of input substitution.

\section{Appendix 2}

\section{Pre- and post-shock results and robustness}

Tables 8 and 9 show the changes in the pre-shock competitive equilibrium of E1 in Fig. 1 to the post-shock competitive equilibrium at E3. As in the main text, we report the results for our preferred benchmark with $\sigma=1.1$ as well as a robustness check when we vary $\sigma$ to be 0.7 and 1.5. As the difficulty in substituting labor across activity types increases from $\sigma$ of 1.5 to 0.7 , the impact of the shocks becomes larger because the industries cannot adjust to the shocks with employment composition but must instead adjust through wages of post-harvest labor.

That the pome industry adjusts better to the shocks is again seen in the labor markets. Despite the smaller loss of pre-harvest employment in the pome industry compared to the prunus industry in percentage terms, the pome industry hires more post-harvest labor in response to the shocks. This is because the output decrease is smaller for the pome industry than the prunus industry. 
Table 8 Pre- and post-shock commodity and labor equilibrium percent change

\begin{tabular}{|c|c|c|c|c|c|c|}
\hline \multirow{2}{*}{\multicolumn{7}{|c|}{$\begin{array}{l}\sigma \quad \text { Output } \\
\text { (Percent change) }\end{array}$}} \\
\hline & & & & & & \\
\hline \multicolumn{7}{|l|}{ Pome } \\
\hline 0.7 & -0.22 & 7.24 & -0.58 & -6.73 & -2.98 & -2.66 \\
\hline 1.1 & -0.16 & 7.10 & -0.60 & -6.70 & -3.83 & -3.48 \\
\hline 1.5 & -0.12 & 7.01 & -0.62 & -6.68 & -4.39 & -4.01 \\
\hline \multicolumn{7}{|c|}{ Prunus } \\
\hline 0.7 & -1.83 & 7.18 & -2.14 & -6.73 & -0.73 & -2.66 \\
\hline 1.1 & -1.69 & 7.05 & -2.08 & -6.70 & -2.24 & -3.48 \\
\hline 1.5 & -1.61 & 6.97 & -2.05 & -6.68 & -3.96 & -4.01 \\
\hline
\end{tabular}

Notes: $e_{\mathrm{s}}=0.73, e_{\mathrm{u}}=3.37,5.4 \%$ final demand shock, and $-7 \%$ pre-harvest labor supply shock

Table 9 Pre- and post-shock commodity and labor equilibrium level change

\begin{tabular}{ccccccc}
\hline$\sigma$ & $\begin{array}{l}\text { Output } \\
(\text { mil. lbs })\end{array}$ & $\begin{array}{l}\text { Price } \\
(\$ / \mathrm{lbs})\end{array}$ & $\begin{array}{l}\text { Pre emp. } \\
(\text { ones })\end{array}$ & $\begin{array}{l}\text { Pre wage } \\
(\$ / \mathrm{h})\end{array}$ & $\begin{array}{l}\text { Post emp. } \\
\text { (ones) }\end{array}$ & $\begin{array}{l}\text { Post wage } \\
(\$ / \mathrm{h})\end{array}$ \\
\hline Pome & & & & & & \\
0.7 & -13.48 & 0.09 & -175.18 & -0.78 & -292.88 & -0.42 \\
1.1 & -9.80 & 0.09 & -181.22 & -0.78 & -376.42 & -0.55 \\
1.5 & -7.35 & 0.09 & -187.26 & -0.78 & -431.46 & -0.63 \\
Prunus & & & & & & -0.42 \\
0.7 & -17.06 & 0.12 & -125.57 & -0.78 & -14.02 & -0.55 \\
1.1 & -15.75 & 0.12 & -122.05 & -0.78 & -45.32 & -0.63 \\
1.5 & -15.01 & 0.12 & -120.29 & -0.78 & -76.04 & \\
\hline
\end{tabular}

Notes: $e_{\mathrm{s}}=0.73, e_{\mathrm{u}}=3.37,5.4 \%$ final demand shock, and $-7 \%$ pre-harvest labor supply shock

Table 10 Supply elasticity for post-harvest labor robustness results

\begin{tabular}{ccccccc}
\hline $\begin{array}{l}e_{s} \\
\text { (Percent change) }\end{array}$ & Output & Price & Pre emp. & Pre wage & Post emp. & Post wage \\
\hline \multicolumn{2}{l}{ Pome } & & & & & \\
0.50 & -0.13 & 7.05 & -0.51 & -6.71 & -3.32 & -3.99 \\
0.73 & -0.16 & 7.10 & -0.60 & -6.70 & -3.83 & -3.48 \\
1.50 & -0.22 & 7.22 & -0.80 & -6.69 & -5.06 & -2.43 \\
2.00 & -0.24 & 7.27 & -0.88 & -6.69 & -5.53 & -2.03 \\
Prunus & & & & & & \\
0.50 & -1.64 & 7.01 & -1.97 & -6.71 & -1.68 & -3.99 \\
0.73 & -1.69 & 7.05 & -2.08 & -6.70 & -2.24 & -3.48 \\
1.50 & -1.81 & 7.16 & -2.32 & -6.69 & -3.39 & -2.43 \\
2.00 & -1.85 & 7.20 & -2.42 & -6.69 & -3.83 & -2.03 \\
\hline
\end{tabular}

Notes: $e_{\mathrm{u}}=3.37, \sigma=1.10,5.4 \%$ final demand shock, and $-7 \%$ pre-harvest labor supply shock 
Though we use the best parameter estimates available from the literature, we also choose other parameters to see how robust our model results are to the parameters specified. Table 10 shows the model's sensitivity to post-harvest labor supply elasticities ranging from 0.5 to 2.0. Though there are some small changes to output, prices, wages, and employment quantitatively, the qualitative result is robust. It is not surprising that as post-harvest labor supply becomes more elastic, that post-harvest wage is less affected but post-harvest wage is more affected. This leads to a greater effect on output and price, as expected, and provides support for our model.

We test the effects when we vary the size of the decrease in pre-harvest labor supply and show the results in Table 11. When the decrease in pre-harvest labor is small such as $2 \%$, then greater demand carries the day and output and prices increase along with wages and employment for both activity types. As that shock gets bigger, it increasingly overwhelms the positive demand shock, leading to outcomes where prices increase substantially even though output declines. In those scenarios, the loss of pre-harvest workers leads to a large wage increase for both activity types and an increased role of post-harvest labor to take over pre-harvest occupations despite the difficulty of switching activity types.

We also test the model's sensitivity to the pre-harvest labor supply elasticities available from the literature in Table 11. Within a given level of decrease in pre-harvest labor, changing the pre-harvest labor elasticity from 3.37 to 2.24 does not change the results much considering how different in size these parameters are. Thus, the results are fairly robust to the elasticity of the pre-harvest labor supply curve.

The results from these robustness checks indicate confidence in the model in that results change as expected. However, the size of the decrease in pre-harvest labor supply

Table 11 Supply elasticity for pre- and post-harvest labor shock robustness results

\begin{tabular}{|c|c|c|c|c|c|c|c|c|}
\hline $\begin{array}{l}\text { Pre-harvest } \\
\text { Labor shift in } \\
\text { (Percent chang }\end{array}$ & $\begin{array}{l}\text { Supply } \\
\text { elasticity for } \\
\text { pre-harvest } \\
\text { labor } \\
\text { ge) }\end{array}$ & Commodity & Output & Price & $\begin{array}{l}\text { Pre-harvest } \\
\text { employment }\end{array}$ & Pre-harvest & $\begin{array}{l}\text { Post-harvest } \\
\text { employment }\end{array}$ & $\begin{array}{l}\text { Post-harvest } \\
\text { wage }\end{array}$ \\
\hline \multirow[t]{4}{*}{$2 \%$} & 2.24 & Pome & 1.87 & 2.80 & 1.85 & 2.78 & 2.06 & 2.63 \\
\hline & & Prunus & 2.95 & 2.80 & 2.93 & 2.78 & 3.13 & 2.63 \\
\hline & 3.37 & Pome & 1.98 & 2.56 & 1.99 & 2.56 & 1.96 & 2.58 \\
\hline & & Prunus & 3.21 & 2.56 & 3.21 & 2.56 & 3.18 & 2.58 \\
\hline \multirow[t]{4}{*}{$5 \%$} & 2.24 & Pome & 0.69 & 5.30 & 0.42 & 5.06 & 3.09 & 3.12 \\
\hline & & Prunus & 0.25 & 5.27 & 0.01 & 5.06 & 2.62 & 3.12 \\
\hline & 3.37 & Pome & 0.70 & 5.29 & 0.43 & 5.05 & 3.08 & 3.12 \\
\hline & & Prunus & 0.26 & 5.26 & 0.03 & 5.05 & 2.62 & 3.12 \\
\hline \multirow[t]{4}{*}{$7 \%$} & 2.24 & Pome & -0.10 & 6.98 & -0.53 & 6.59 & 3.78 & 3.45 \\
\hline & & Prunus & -1.56 & 6.93 & -1.94 & 6.59 & 2.27 & 3.45 \\
\hline & 3.37 & Pome & -0.16 & 7.10 & -0.60 & 6.70 & 3.83 & 3.48 \\
\hline & & Prunus & -1.69 & 7.05 & -2.08 & 6.70 & 2.24 & 3.48 \\
\hline \multirow[t]{4}{*}{$11 \%$} & 2.24 & Pome & -1.67 & 10.32 & -2.43 & 9.63 & 5.16 & 4.11 \\
\hline & & Prunus & -5.16 & 10.24 & -5.83 & 9.63 & 1.58 & 4.11 \\
\hline & 3.37 & Pome & -1.87 & 10.74 & -2.67 & 10.01 & 5.33 & 4.19 \\
\hline & & Prunus & -5.61 & 10.65 & -6.31 & 10.01 & 1.49 & 4.19 \\
\hline
\end{tabular}

Notes: $\sigma=1.10, e_{\mathrm{s}}=0.73$, and $5.4 \%$ final demand shock. Supply elasticity of 2.24 is from Rosenbloom (1991) and 3.37 is from Perloff (1991) 
plays a large and important role in the magnitude of the effects and those of the welfare losses. Our welfare estimates are sensitive to the size of this shock relative to the demand increase shock.

As a final robustness check, we assess the sensitivity of our results to the price elasticity of demand for pome. Our main results use the estimate of the price elasticity of demand reported in Henneberry et al. (1999) of -0.59, which was obtained using data from 1970 to 1992. But the pome market, in particular the apple market, experienced large changes beginning in the 1990s as foreign varieties such as Gala and Fuji were introduced. The much more recent estimate from Okrent and Alston (2012) was obtained using data from 1998 to 2010. They find a nearly identical price elasticity of demand of -0.60 despite the varietal and preference changes in the apple market. Zheng (2010) estimates the price elasticity of demand by variety using data from 1998 to 2006. She estimates the elasticity for Red Delicious to be -0.60 . Of the other varieties, the biggest difference is for Gala. Zheng estimates the price elasticity for Gala to be -0.34 . But Gala is only $12 \%$ of the market. The weighted average of the price elasticity of demand is -0.49 .

To show the robustness of our results to these estimates, Table 12 repeats the welfare impacts from Table 7-for the pome market only-using different values of the price elasticity of demand from Henneberry et al. (1999), Okrent and Alston (2012), and Zheng (2010). As can be seen, the quantitative results are nearly the same using the Henneberry et al. and the Okrent and Alston estimates. Thus, despite the shift in consumer preferences for apple varieties, the estimated price elasticity of demand from our two main sources are quite similar $(-0.60$ vs -0.59$)$ regardless of the period the data were obtained. When we consider the effect of new varieties, the price elasticity become smaller (in absolute value) and the damages to overall welfare from the shocks increase dramatically. If we use only the price elasticity for Gala of -0.34 , the welfare impact is massive ( $-\$ 567$ million). Thus, we consider our reported results as quantitatively conservative. We note that for all cases, our results are qualitatively in agreement.

Table 12 Price elasticity of demand welfare impact robustness results

\begin{tabular}{|c|c|c|c|c|c|c|c|c|}
\hline \multirow[b]{2}{*}{ Source } & \multicolumn{8}{|c|}{ Pome commodity market (million \$) } \\
\hline & $\begin{array}{l}\text { Data } \\
\text { period }\end{array}$ & $\begin{array}{l}\text { Price } \\
\text { elast. }\end{array}$ & Surp. & $\begin{array}{l}\text { Post-shock } \\
\text { CE }\end{array}$ & $\begin{array}{l}\text { Post-shock } \\
\text { fixed wage }\end{array}$ & $\begin{array}{l}\text { Welfare } \\
\text { change }\end{array}$ & $\begin{array}{l}\text { Post-shock fixed } \\
\text { wage Trans. }\end{array}$ & $\begin{array}{l}\text { Welfare change } \\
\text { trans. }\end{array}$ \\
\hline \multirow{3}{*}{$\begin{array}{l}\text { Henneberry } \\
\text { et al. (1999) }\end{array}$} & \multirow[t]{3}{*}{ 1970-1992 } & \multirow[t]{3}{*}{-0.59} & Cons. & 8032.6 & 6788.0 & -1244.6 & 1344.1 & -6688.5 \\
\hline & & & Firm & 1002.2 & 2187.9 & 1185.7 & 1002.2 & 0.0 \\
\hline & & & Total & 9034.8 & 8975.9 & -58.9 & 2346.3 & -6688.5 \\
\hline \multirow{3}{*}{$\begin{array}{l}\text { Okrent \& } \\
\text { Alston (2012) }\end{array}$} & \multirow[t]{3}{*}{ 1998-2010 } & \multirow[t]{3}{*}{-0.60} & Cons. & 7876.4 & 6648.9 & -1227.5 & 1348.0 & -6528.4 \\
\hline & & & Firm & 999.2 & 2172.6 & 1173.4 & 999.2 & 0.0 \\
\hline & & & Total & 8875.6 & 8821.5 & -54.2 & 2347.2 & -6528.4 \\
\hline \multirow[t]{3}{*}{ Zheng (2010) } & \multirow[t]{3}{*}{ 1998-2006 } & \multirow[t]{3}{*}{-0.49} & Cons. & 9607.0 & 7819.2 & -1787.8 & 1107.1 & -8499.9 \\
\hline & & & Firm & 985.3 & 2537.3 & 1552.0 & 985.3 & 0.0 \\
\hline & & & Total & $10,592.3$ & $10,356.4$ & -235.8 & 2092.4 & -499.9 \\
\hline
\end{tabular}

Source: Authors' calculations 


\section{Acknowledgements}

We thank Mike Brady and Xiaojiao Jiang for important conversations on developing the model. We also thank seminar participants at Penn State University and the Pacific Northwest Regional Economic Conference. State funds for this project were matched with Federal funds under the Federal-State Marketing Improvement Program of the Agricultural Marketing Service, U.S. Department of Agriculture, 2013. This work was supported by the USDA National Institute of Food and Agriculture, Hatch Project 0544

\section{Authors' contributions}

AC conceived of the research project, designed the method, interpreted the results and the economics, and wrote the manuscript. KL obtained and analyzed the data, calculated the equilibrium and welfare values, conducted the literature review, and provided supporting research. JS provided expertise on the transportation section. PT provided expertise on agricultural data and markets. All authors read and approved the final manuscript.

\section{Competing interests}

The authors declare that they have no competing interests.

\section{Publisher's Note}

Springer Nature remains neutral with regard to jurisdictional claims in published maps and institutional affiliations.

\section{Author details}

${ }^{1}$ School of Economic Sciences, Washington State University, Pullman, WA, USA. ${ }^{2}$ Institute for Tourism \& Recreation, University of Montana, Missoula, MT, USA. ${ }^{3}$ Institute for Agriculture and Environment, University of Massey, Palmerston North, New Zealand.

Received: 28 August 2017 Accepted: 2 August 2018 Published online: 19 September 2018

\section{References}

Blackburn J, Scudder G (2009) Supply chain strategies for perishable products: the case of fresh produce. Prod Oper Manag 18(2):129-137

Bogataj M, Bogataj L, Vodopivec R (2005) Stability of perishable goods in cold logistic chains. Int J Prod Econ 93:345-356.

Brady MP, Karina Gallardo R, Badruddozza S, Jiang X (2016) Regional equilibrium wage rate for hired for hired farm workers in the tree fruit industry. West Econ For 15(1):20-31.

Brat, Ilan (2015) 'On U.S farms, fewer hands for the harvest.' Wall Street J. http://www.wsj.com/articles/on-u-s-farms-fewerhands-for-the-harvest-1439371802 (Accessed 29 Dec 2016).

Card D, Lemieux T (2001) Can falling supply explain the rising return to college for younger men? A cohort-based analysis. Q J Econ 116(2):705-746.

Costello, Bob, and Rod Suarez (2015) Truck driver shortage analysis. American Trucking Associations report, http://www. trucking.org/ATA/\%20Docs/News/\%20and/\%20Information/Reports/\%20Trends/\%20and/\%20Statistics/10/\%206/\%2015/ \%20ATAs/\%20Driver/\%20Shortage/\%20Report/\%202015.pdf (Accessed 1 Mar 2016).

Duffield, James A. (1990) Estimating farm labor elasticities to analyze the effects of immigration reform. U.S. Department of Agriculture, Economic Research Service, Agricultural and Rural Economy Division, ERS staff report no. AGES 9013.

Fisher DU, Knutson RD (2013) Uniqueness of agricultural labor markets. Am J Agric Econ 95(2):463-469.

Fyksen, Jane (2015)'Labor shortage puts food-supply at risk.' Agri-View. https://www.agupdate.com/agriview/news/crop/laborshortage-puts-food-supply-at-risk/article_78377b01-43b7-5bb0-ac7d-59af1f54f721.html (Accessed 1 Mar 2016).

Gunter LF, Jarrett JC, Duffield JA (1992) Effect of U.S. immigration reform on labor-intensive agricultural commodities. Am J Agric Econ 74(4):897-906.

Henneberry SR, Piewthongngam K, Qiang H (1999) Consumer food safety concerns and fresh produce consumption. J Agric Resour Econ 24:98-113.

Hertz T, Zahniser S (2013) Is there a farm labor shortage? Am J Agric Econ 95(2):476-481.

Jessup E, Herrington R (2005) Estimating the impact of seasonal truck shortages on the movement of time-sensitive, perishable products: transportation cost minimization approach. Trans Res Rec 1906(1):81-88.

Kader AA (2005) Increasing food availability by reducing post harvest loss of fresh produce. Acta Horticulturae 682:2169-2176 V International Postharvest Symposium 682.

Kantor LS, Lipton K, Manchester A, Oliveira V (1997) Estimating and addressing America food losses. Food Rev 20(1):2-12. Kidd J, Padgett J (2016) Trucker shortage as government failure. J Regulat Comp 1(1):1-20.

Min H, Lambert T (2002) Truck driver shortage revisited. Transp J 42(2):5-16.

Mongelluzzo, Bill (2015) 'U.S warehouse, logistics sector warned of labor shortage.' J Comm. http://www.joc.com/truckinglogistics/labor/us-warehouse-logistics-sector-warned-labor-shortage_20150929.html (Accessed 31 Dec 2016).

Morris, David Z. (2015) There's a slow-rolling crisis in trucking labor-and it's costing everyone.' Fortune http://fortune.com/ 2015/05/18/trucking-labor-shortage/ (Accessed 29 Dec 2016).

Muth RF (1964) The derived demand curve for a productive factor and the industry supply curve. Oxf Econ Pap 16(2):221-234

Okrent AM, Alston JM (2012) The demand for disaggregated food-away-from-home and food-at-home products in the United States. Economic Research Report No. 139, United States Department of Agriculture-Economic Research Service, Washington, DC.

Perloff JM (1991) The impact of wage differentials on choosing to work in agriculture. Am J Agric Econ 73(3):671-680.

Richards TJ, Patterson PM (1998) Hysteresis and the shortage of agricultural labor. Am J Agric Econ 80:683-695.

Rosenbloom JL (1991) Occupational differences in labor market integration: the United States in 1890. J Econ Hist 51(2):427-439.

Taylor JE, Charlton D, Yu'nez-Naude A (2012) The end of farm labor abundance. Appl Econ Perspect Policy 34(4):587-598.

USDA-ERS (2014) Fruit and tree nut yearbook. United States Department of Agriculture-Economic Research Service,

Washington, DC. 
USDA-NASS (2014) Noncitrus fruits and nuts summary. United States Department of Agriculture-National Agricultural Statistics Service, Washington, DC.

Wells, Jane (2012) 'California farm labor shortage 'worst it's been, ever.'. CNBC. http://www.cnbc.com/id/48725145\# (Accessed 10 Nov 2014).

Zheng Q (2010) Production, consumption and risk in agricultural economics. Dissertation, School of Economic Sciences, Washington State University.

Submit your manuscript to a SpringerOpen ${ }^{\odot}$ journal and benefit from:

- Convenient online submission

- Rigorous peer review

- Open access: articles freely available online

- High visibility within the field

- Retaining the copyright to your article

Submit your next manuscript at $\boldsymbol{\nabla}$ springeropen.com 